\title{
Research on Urban Indemnificatory Housing with Suitable Crowd and its Housing Component Type
}

\author{
Sun Kezhen
}

College of Architecture and Urban Planning, Bei-

jing Civil Engineering Architectural Design \& Research Institute, Beijing University of Civil Engineering and Architecture, Beijing 100044, China

\begin{abstract}
This article discusses housing security system in our society. From the society attribute this paper gives account of the housing security problem under the different social conditions. The article argues the critical roles of housing security system under the modern society. The paper also reviews the progress from welfare or public room to indemnificatory or affordable housing in China, and many essential characteristics are well analyzed. The study about urban indemnificatory housing with suitable crowd and its housing component type becomes more and more vital problem which involves housing security system in China, and the paper probes into suitable crowd and its housing component type.
\end{abstract}

Keywords: Urban, Indemnificatory housing, Suitable crowd, Component type

\section{Introduction}

Inhabitation problem is not only an important problem of life but also a residential building problem, as well as a significant social problem, which is concerned with the stability of a society. And the problem has a momentous meaning for any country or society and that problem is the window of a nation's basic economic strength. Therefore inhabitation problem possesses the attribute of society.

China as a socialist country had always been insisting on the developments of public and welfare housing since 1949 . At that time collected science and technology strength in the country, the planning and design of welfare residential buildings had developed gradually, which was economical and adaptable, and their system of standards, technical and economic indexes had been shaped relatively maturely. With the development of China's reform, opening up and the practice of market economy, including a social housing security system, a series of social security systems is being gradually set up and perfected.

2. The social attribute of residential problem

2.1 The social development and residential problem should be coordinated growth

There is a very definite link between people's survival condition and social development. Since people came to modern society, industrialization and urbanization it has brought many social problems into a series of social crises, such as ecological environment and living space etc. And the situation has become increasingly grave. The problems of human's survival environment, harmonious society have 
become more and more importance. The contradictions among polarizations of wealth and social equity always are some main social problems. Each problem, such as obtain employment, income, housing and Medicare etc. is concerned with stabilization of society.

Observing the development of human society indicates that it is one of the important guarantees of harmonious society to establish a social security system for low-income people's survival condition. From the practice of different social system, there is an extensive meaning to establish the social security, and facing common social problem. In different countries and regions the state of social security system in low-income and vulnerable people's survival and to obtain employment, medical treatment, and housing should reflect the different characters of political system. Historically after industrial society and some social crisis in many western countries, many related policies have continually been adjusted, and social security system has constantly been established. Some social security systems have been explored and established for a long time in many western countries and some other regions. Therefore, from that, we can learn more about experiences for our developing country. Indeed, the living state of lowincome people, the social housing security system or the social security system will determine whether a country, a society is successful or not, no matter how high science, technology and national defense strength of one's country. Therefore the living state of low-income people, the social housing security system is one of the most important symbols of one's country development.

\subsection{Referring to successful experience of a housing security system overseas}

By using the experience of several countries and regions that have the earlier established a social housing security system:
The levels of one country's a large number of residential constructions are concerned with its social security, environment quality, and harmony social system. Establish a social security system, which is concerned with the society stability and harmony. Indemnificatory housing and its residential environment, and supporting facilities construction can relieve social contradictions. By using the experience of several countries and regions that have the earlier established a social housing security system, for instance, Public Housing in Hong Kong, State Apartment in Singapore, Indemnificatory Housing and housing security system in Japanese, America, Canada, and some European countries etc. It has an important meaning for perfecting China's housing security system. State Apartment and Garden City construction in Singapore not only improves the residential conditions, but also beautifies residential area, public community, and urban environment. There is not only Home Ownership, but also Shop Ownership in the Singapore.

\section{The basic characteristics of afforda- ble housing in China}

\subsection{The housing security system in China}

Although the history of our socialist China is relatively younger than some developed country, but the explorations of welfare or public house construction had already started since 1949 . Therefore we have already had a certain foundation to establish a housing security system. From the planned economy period, the early year of our country, to the reform and opening up period the practice of public or welfare house in our country had experienced different economic development stages. Each social security system is being gradually set up and adjusted experiencing short-term explora- 
tion. Therefore, using for reference overseas experiences and practices our socialist China will become the advanced representation of social housing security system under our government leadership and investment. Especially in recent years it has become our clear objectives to establish and continuously improve social housing security.

\subsection{The housing security system coin- cides with its socialist system}

The characteristics of China's socialist system will decide on its distinct feature of housing security system. The aim of China's housing security system is improving dwelling condition for lowincome people. This housing security system includes different kinds of affordable or indemnificatory housing, and the aim is not for profit but good residential environment and harmonious society. The indemnificatory housing is not low standard rough housing; it has been on the basis of built and studied on economical and adaptable housing by the time our country is established; and it has the basis level of ordinary housing. The indemnificatory housing should strictly be built according to state standards, and the function of housing, construction area and cost are accord with national technology standards.

3.3 The housing security system in China is being established and practiced

The social security system in China is still being established, and the Party and Country are actively promoting the establishment of our housing security system. According to the problems in the practice many policies and guidelines are constantly readjusted and improved. Under the unified arrangements of the central government, according to the actual situation every local government are actively probing, practicing, and constantly perfecting local standards about housing se- curity system. Different kinds of indemnificatory housing had been established such as economic affordable housing, low-rent housing, and affordable public rental housing, public rental housing and economic affordable housing etc. The object of indemnity, the scope of the crowd who should be guarantied is constantly extending.

\section{Urban Indemnificatory Housing with Suitable Crowd and its housing Component Type}

\subsection{Urban Indemnificatory Housing with Suitable Crowd}

The study about urban indemnificatory housing with suitable crowd and its housing component type becomes more and more vital problem which involves housing security system in China. At present there are many exposed problems in the practices of China's indemnificatory housing. These problems include: problem with efficiency and effectiveness about the indemnificatory housing, fewer type and lacking variety for whole suitable crowd, the definition of the scope of population who should be benefited from indemnificatory housing, and types of indemnificatory housing to adapt to the era development, new suitable crowd who comes accompanied with rapid China's urbanization etc. It has been a trend to expand the object of indemnity and scope of suitable crowd benefited from indemnificatory housing. It is the time that we studied the problem of the object of urban indemnificatory housing and its suitable crowd. The objects of indemnity are not only existing lowincome families in the city but also including new urban people and city flowing population who are low-income family, and come from rural area and small-town, and they have integrated into the urban life. 


\subsection{Component type of urban indem- nificatory housing:}

The most important and innovative research contents concerned with indemnificatory housing security system of China are listed below: various kinds of function component, layout and arrangement characteristics, and related design standards and economic indexes about indemnificatory housing; economic affordable housing, price-limit housing, public rental housing and public low-rent housing etc. Deeply analyze in various kinds of indemnificatory housing and their object of indemnity, not only ordinary existing buildings of apartment which have served urban people but also other new kinds of dwelling mode and its housing for suitable crowd who are new urban people and come from rural area. That housing security system should include some small-sized and low-cost apartment housing, and low-rent flat, and many kinds of resident mode etc. which are fit for city flowing population. The cohousing community and co-rented apartment housing which shares community resource and facilities with several families in an apartment housing unit can greatly reduce the economic cost of the apartment housing.

\section{Conclusion}

Housing security system is developed out of the growth of the modern civilizations. Inhabitation problem possesses the attribute of society. The living state of lowincome people, the social housing securi- ty system is one of the most important symbols of one's country development.

China's indemnificatory housing should possess the advantage of socialistic system. It is the basic representative of advanced in ecology and economics, and it will be reflected in a country's comprehensive strength of the economy and society. The study about urban indemnificatory housing with suitable crowd and its housing component type becomes more and more vital problem which involves housing security system in China.

\section{References}

[1] Quan Xin, Operation Concept and Construction Pattern of Affordable Private - rental Housing in America: Based on the Successful Experience of EAH, ARCHITECTURAL JOURNAL 2011.8, Beijing China

[2] Liu Jiaoming, Difference between Welfare-oriented Housing of China and Public-operated Residences of Japan, HOUSING SCIENCE 2010.8, Shanghai China

[3] Wang Danna, $\mathrm{Hu}$ Zhenyu, State Apartment Construction in Singapore and the Enlightenment, HOUSING SCIENCE 2010.5, Shanghai China

[4] Zhou Dian, Planning and Design for Japanese Indemnificatory Housing, ARCHITECTURAL JOURNAL 2009.8, Beijing China

[5] Zhang Rui, A new living concept based on Low-impact strategy: The sustainability of Cohousing community, THE ARCHITECT JUNE 2011/3 No.151, Beijing China 